\title{
Klingsor syndrome: A rare surgical emergency
}

\author{
Gaurav Aggarwal, M.D., Samiran D Adhikary, M.D.
}

Department of Urology, Apollo Hospital, Bhubaneshwar, Odisha-India

\begin{abstract}
Klingsor syndrome or self-Inflicted traumatic penile amputation is a rare clinical entity that is associated with psychiatric disorders, command hallucinations, religious preoccupations, substance abuse, and isolation from or neglect by society. In addition to being infrequently encountered, it is a rare surgical emergency, with paucity of data on appropriate and timely management to ensure optimal functional outcomes. We report the case of a 25 -year-old unmarried male who inflicted this injury upon himself in a fit of paranoia as a way to expiate his sins and earn solace from God. An attempt at microvascular re-implantation $12 \mathrm{~h}$ after the injury was successful, with adequate cosmetic and functional outcomes obtained. Thus, in this rare disease, despite a delay in presentation, a single attempt at re-implantation may still be worthwhile for obtaining optimal cosmetic and psychosocial benefits.
\end{abstract}

Keywords: Klingsor syndrome; penile self-amputation; urological emergency.

\section{INTRODUCTION}

Klingsor syndrome or self-Inflicted traumatic penile amputation is a rare clinical entity; it is usually associated with psychiatric disorders, command hallucinations, religious preoccupations, substance abuse, and isolation from or neglect by society. ${ }^{[1,2]}$ It is infrequently encountered and is a rare urological emergency; there is paucity of data on this syndrome in terms of adequate and timely management.

We report the case of a 25-year-old unmarried male who inflicted this injury upon himself as a way to expiate his sins and earn solace from God. An attempt at microvascular reimplantation 12 hours after the injury was successful with adequate cosmetic and functional outcomes obtained.

\section{CASE REPORT}

A 25-year-old unmarried male with no past medical or psychiatric history was brought to the emergency department in a hemodynamically stable condition and with a self-inflicted

Address for correspondence: Gaurav Aggarwal, M.D.

Department of Urology, Apollo Hospital Bhubaneshwar, India Tel: +91-7873947779 E-mail: drgaurav1981@rediffmail.com

Submitted: 26.05 .2016

Accepted: 16.01.2017

Ulus Travma Acil Cerrahi Derg

2017;23(5):427-429

doi: $10.5505 /$ tjtes. 2017.30346

Copyright 2017

TJTES penile injury; the amputated distal penile appendage was in a clean dry bag. He had self-mutilated himself around $12 \mathrm{~h}$ ago at the behest of "inner commanding voices" that had "reassured" him of complete solace and expiation of his sins.

Despite the long duration, post trauma, the appendage appeared viable; therefore, with adequate consent, an attempt at re-implantation was planned.

The patient was immediately taken to the operation theatre (Figure I). The patient was injected with amoxicillin/clavulanic acid under general anesthesia; microvascular re-implantation of the penile appendage was performed (using prolene 8-0 and 9-0 interrupted sutures; under $2.5 \times$ magnification), ensuring adequate debridement of nonviable tissues. The immediate postoperative appearance was cosmetically acceptable (Figure 2).

The postoperative course of the patient was uneventful, with evaluation and initiation of psychiatric treatment (with a diagnosis of paranoid schizophrenia) and oral ketoconazole for 10 days postoperatively to prevent immediate penile engorgement. He was discharged on the eight postoperative day without any event. At the 2-month follow up, he was asymptomatic and his cosmetic and functional outcomes were adequate.

\section{DISCUSSION}

Self-inflicted penile amputation is an extremely uncommon injury, with literature reports stating that approximately $87 \%$ 


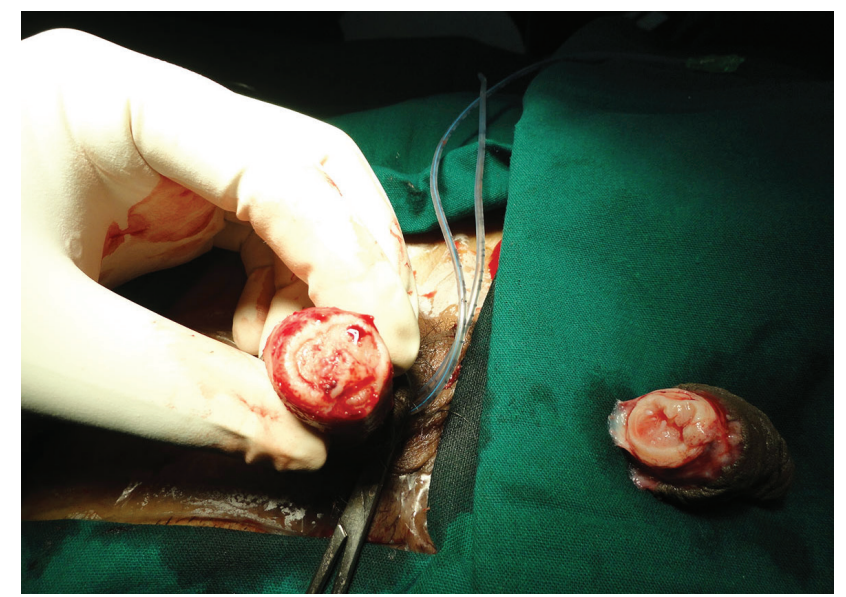

Figure 1. Preoperative appearance, after local tissue debridement.

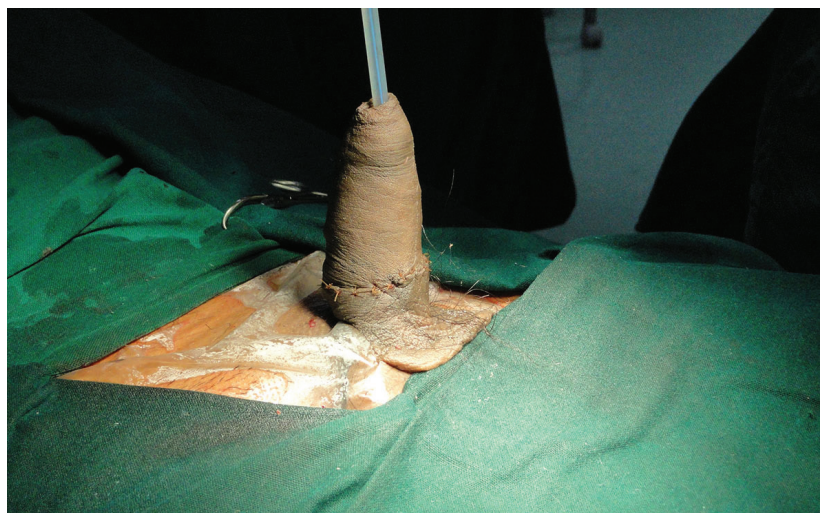

Figure 2. Immediate postoperative appearance.

of patients suffer from undiagnosed psychiatric disorders and around $51 \%$ of these have "decompensated schizophrenia". ${ }^{[1,2]}$ Some patients may be socially isolated due to severe bipolar depression or due to them having religious delusions. ${ }^{[3]}$ Various risk factors implicated in reports worldwide include elderly single males, trans-sexual or homosexual tendencies, or as a guilty feeling for self-committed sexual offences. ${ }^{[2-4]}$

Irrespective of the underlying etiology, Klingsor syndrome is an important urological emergency, mandating early and prompt treatment, to achieve optimal prognosis. Being infrequently seen, there are no set management protocols.

In 1929, Ehrlich was the first to document a case of macroscopic penile re-implantation; in 1977, Cohen et al. reported on the first microvascular re-implantation. ${ }^{[4]}$ It has been postulated that as microsurgical techniques minimize the skin, urethra, and graft loss as well as enable better vascular and nerve repair, they may be more beneficial in preserving the sensation of the organ, micturition, and erectile function. ${ }^{[5-7]}$

The use of non-microsurgical techniques has also been reported with varying degrees of success, and a review by Volkmer et al ${ }^{[6]}$ even questioned the value of these microsurgical techniques. ${ }^{[7]}$
Both microscopic as well as non-microscopic techniques have provided equivocal results in various reports, considering the fact that repair of a single dorsal penile artery may be more important than repairing multiple profunda arteries. ${ }^{[7]}$

Although re-implantation is the gold standard, it may always not be possible to achieve the same on account of significant local ischemia and prolonged duration post trauma. ${ }^{[5]}$ In our case, despite the long duration, a single attempt at re-implantation was made, with consent received from the patient's relatives after they were explained about the guarded prognosis. Circumcision should be avoided as the preputial skin may be an important appendage for use in future reconstructions, if necessary.

In instances of delay at presentation, other options include closure of the distal stump or phallic replacement and reconstruction after the acute injury has healed..$^{[5]}$ The adequate length of the phallus to be kept for adequate postoperative functioning is debatable and depends on the level of penile injury as well as the surgical expertise. ${ }^{[5]}$

Postoperative complications include local skin loss, which is common, and penile necrosis and urethrocutaneous fistulae, which are rare. ${ }^{[8]}$

Nevertheless, microvascular re-implantation remains the treatment of choice with the highest probability of adequate cosmetic as well as functional outcomes. ${ }^{[5,8]}$

A concomitant psychiatric evaluation is mandatory to ensure optimal functional outcomes and prevent such occurrences in the future. In our case a diagnosis of "paranoid schizophrenia" was made, and the patient was promptly initiated on medications for the same. Such patients need long-term follow-up to ensure effective psychosocial rehabilitation in addition to support from the society and family in particular.

\section{Conclusion}

Self-inflicted penile amputation is a rare urological emergency that mandates immediate and timely surgical intervention to ensure optimal cosmetic and functional outcomes. The ideal management algorithm however depends on a multidisciplinary approach involving a urologist as well as a psychiatrist. Till such time, we have to rely on isolated case reports to ensure awareness on this entity.

A single attempt at re-implantation, without circumcision, despite a slightly prolonged delay at presentation, may be worthwhile, taking into account future cosmesis and functionality.

Conflict of interest: None declared. 


\section{REFERENCES}

1. Bhargava SC, Sethi S, Vohra AK. Klingsor Syndrome: A Case Report. Indian J Psychiatry 2001;43:349-50.

2. Kochakarn W. Traumatic amputation of the penis. Braz J Urol 2000;26:385-9.

3. Ozan E, Deveci E, Oral M, Yazici E, Kirpinar I. Male genital self-mutilation as a psychotic solution. Isr J Psychiatry Relat Sci 2010;47:297-303.

4. Bhatt YC, Vyas KA, Srivastava RK, Panse NS. Microneurovascular reimplantation in a case of total penile amputation. Indian J Plast Surg
2008;41:206-10. [CrossRef]

5. Wei FC, McKee NH, Huerta FJ, Robinette MA. Microsurgical replantation of a completely amputated penis. Ann Plast Surg 1983;10:317-21.

6. Volkmer BG, Maier S. Successful penile replantation following autoamputation: twice! Int J Impot Res 2002;14:197-8. [CrossRef]

7. El Harrech Y, Abaka N, Ghoundale O, Touiti D. Genital self-amputation or the Klingsor syndrome: Successful non-microsurgical penile replantation. Urol Ann 2013;5:305-8. [CrossRef]

8. Kochakarn W, Muangman V, Krauwit A. Traumatic penile amputation: results with primary reattachment. J Urol 1997;157:857.

\section{OLGU SUNUMU - ÖZET}

\section{Klingsor sendromu: Seyrek görülen cerrahi acil}

\section{Dr. Gaurav Aggarwal, Dr. Samiran D Adhikary}

Apollo Hastanesi, Üroloji Kliniği, Bhubaneshwar, Odisha, Hindistan

"Klingsor sendromu" veya "kişinin kendi penisini ampüte etmesi" seyrek görülen bir klinik durum olup psikiyatrik bozukluklar, emir alma varsanısı, dinsel saplantılar, madde kötüye kullanımı, toplumdan izole edilme veya ihmal edilme ile ilişkilidir. Nadiren rastlandığı gibi seyrek görülen bir cerrahi acildir. Optimal sonuçları güvence altına alma amacıyla uygun ve zamanında tedavi açısından yetersiz veri mevcuttur. Yirmi beş yaşında bekâr, günahlarının kefaretini ödeme ve Tanrının affını kazanma yöntemi olarak penisini yaralamıştır. Yaralanmadan I2 saat sonra gerçekleştirilen mikrovasküler reimplantasyon çabası yeterli kozmetik ve fonksiyonel sonuçlarıyla başarılı olmuştur. Bu seyrek görülen hastalıkta gecikmeye rağmen optimal kozmetik ve psikososyal yararlar için tek bir reimplantasyon denemesi bile zahmete değer.

Anahtar sözcükler: Klingsor sendromu; penis; penisini ampüte etme; ürolojik acil.

Ulus Travma Acil Cerrahi Derg 2017;23(5):427-429 doi: 10.5505/tjtes.2017.30346 